\title{
Introduction.
}

\section{Making the Past in Late and Post-Carolingian Historiography}

\author{
Maximilian Diesenberger*
}

This article focuses on how different pasts were constructed in the late and post-Carolingian world. In order to create a past, authors active around the year 900 chose different strategies: they made use of specific text formats in order to distance themselves from the past; they drew on alternative sources and a new vocabulary. They changed the scale of their observation and took new liberties with their narratives, as they were not as firmly bound to inherited narratives as their predecessors had been. This had an effect on their authorial posture within their texts. Through their specific use of the past, these authors not only attempted to provide an image of a new reality - they went beyond this. By breaking off the present from the past, or emphasising certain aspects of the past while "forgetting " others, they were making an important contribution to the re-formation of their world.

Keywords: Carolingians; historiography; annals; social memory; empire; kingdoms

"The past was a very real presence in early medieval societies. It might provide a legitimating template for the current order of things, explaining how things were meant to be thus, or an image of an ideal order, a Golden age against which the present could be judged. Within a social group, shared beliefs about the past were a source of identity: the image of a common past informed a >Wir-Gefühl (a sense of >us-ness`), and the defining characteristics of that past identified those who were and were not part of 'us in the present. « ${ }^{1}$

This is how Matthew Innes introduced the volume The Uses of the Past in the Early Middle Ages (Hen and Innes) in 2000. The essays collected in this volume cover the period between 600 and 1200 in Italy, England and on different parts of the continent. This themed issue, however, concentrates on times of transition in the late and post-Carolingian world in western Europe as well as in tenth- and eleventh-century Georgia, Armenia and in Islamic Spain. One article even takes medieval China into account. In all these societies transformations took place, albeit for different reasons.

* Correspondence details: Maximilian Diesenberger, Institute for Medieval History, Austrian Academy of Sciences, Hollandstraße 11-13, 1020 Vienna, Austria; email: max.diesenberger@oeaw.ac.at.

This work was written as a contribution to the colloquium "Uses of the Past in Times of Transition. Forgetting, using and discrediting the past", the final conference of the HERA Joint Research Project "After Empire. Using and not using the past in the crisis of the Carolingian world, c. 900-1050", held in Vienna from 30th May to 1st June 2019.

1 Innes, Using the past, 1. See also Geary, Phantoms of Remembrance; Gantner et al., Resources of the Past, especially Pohl and Wood, Introduction. For new perspectives on the relation between historiography and identity see Pohl, Historiography. I would like to thank Richard Corradini, Paul Gazzoli, Thomas Gobbitt, Simon MacLean, Walter Pohl, Helmut Reimitz and Jelle Wassenaar for comments on this text. 
In the Latin West the Frankish Empire gave way to multiple different kingdoms, where Carolingian practices and (textual) traditions were more or less open to competition. In tenth-century Muslim Spain the Umayyad dynasty subdued all rebellions against their rule in al-Andalus, which was helped by profound changes in the Andalusi society, especially the processes of social Arabisation and Islamisation. In the same period, Byzantine expansion changed the political landscape of Armenia, with ambivalent reactions from the region's nobles. In Georgia, the kingdom of Kartli was repeatedly ravaged by Arabs and Persians, exacerbating the religious conflicts within the country. Political instability also prevailed in tenth-century China, the five dynasties period. These events and processes changed the social order within, or even the identity of, the respective societies and made the re-evaluation and re-formulation of their pasts necessary.

In what follows, some observations of how different pasts were constructed in the late and post-Carolingian world are presented, in order to open the topic up for discussion on a larger scale. The construction of the past is first and foremost a question of scale. While changes happened all the time in different localities and were also accompanied by texts, »times of transition « meant changes on a larger scale, whereby "scales « and "ranges« were themselves subject to transformation. An additional aspect is the complexity of the changes. These included not only the breakdown of the political system but also changes in the economic, cultural and social structures. In this paper I will focus on how the narrators of this period spoke about the past: which scales they chose, which sources and vocabularies they used to address changes in the social field, which genre they chose in the first place, how much freedom of story-telling they had and how they understood themselves as authors. But first and foremost in such periods, we sense the authors' awareness of living in their specific time period.

In 906 Regino of Prüm, for instance, writes in the introduction to his text De synodalibus causis to Archbishop Hatto of Mainz about the present as "dangerous times, a very bad time" (periculosa tempora, pessimum tempus). ${ }^{2}$ Several of his contemporaries shared this view. Bishop Salomon of Constance sees only the collapse of morals, the brutalisation of human behaviour, the dissolution of cohesion, the lack of solidarity on all levels of society and even within families. ${ }^{3}$ The participants in the Council of Trosly in 909 formulated things in a similar manner. ${ }^{4}$

At the same time, Bishop Dado of Verdun, confronted with his flock's fear of the apocalyptic Hungarian raiders, had to console himself with the words of Gregory the Great: »Our hardships have grown, everywhere we are surrounded by swords, everywhere we fear the imminent danger of death ", and so he continues: "What then remains for us, except to give thanks with tears while we endure the chastisements that we suffer on account of our sins? ${ }^{5}$ Such judgements of the present are not confined to the early years of the tenth century. Quite the opposite: the synods from the middle of the ninth century onwards lament the tempus turbulentissimum (c. 850), ${ }^{6}$ tempora angusta $(871)^{7}$ and tempora periculosa (Fismes 881$){ }^{8}$

\footnotetext{
Regino of Prüm, Libri duo de synodalibus, ed. Hartmann, 21.

Salomon of Constance, Carmen, ed. von Winterfeld, 301.

Synod of Trosly, ed. Hartmann et. al., 503-504.

Epistola de Hungaris, ed. Heilig, 16. See also Huygens, Témoin de la crainte.

Synod of Moret (c. 850), ed. Hartmann, 233.

Synod of Doucy, ed. Hartmann, 503 and 505.

Synod of Fismes, ed. Hartmann et al., 178.
} 
The participants in the Council of Tribur (895) felt it necessary to set up a novum paradigma to counter the attacks of Satan and his followers. ${ }^{9}$ Even in 920, such voices had not fallen silent, such as when Abbo of Saint Germain complained that the regnum was collapsing day by day, and that all the kings who had once protected the empire were long dead. ${ }^{10}$ This assessment of the times had a point, even if drastic events had happened previously: the strife between Louis the Pious' sons, which reached its high point in 841; the battle of Fontenoy; almost annual Viking attacks; the incursions of the Hungarians; the empire drifting apart into several pieces, and the death of Charles III - the last emperor, at least in West Frankish perception.

In this generation of authors, a feeling of "lateness « had spread, a feeling of being at the end of an era and at the end of a chain of developments. Regino put this into words in his letter to Hatto when he labelled the present a "decrepit age (decrepita aetas). ${ }^{11}$ This has an eschatological touch, as the final age of the world in Bede and other authors, the sexta aetas. Regino also laments the scholarship which acquits itself so poorly in comparison to that of "inventive Latin antiquity" (sollers latialis antiquitas). ${ }^{12}$ But the ideology of the sexta aetas per se was not necessarily a negative one. Almost at the same time (881), the unknown author of the Chronicle of Albelda also recognises in the kingdom of Asturia the end of the same (sixth) era. In this case, however, the author provides some positive impetus for the fight by the Christians against the Muslims in Spain.

This feeling of "lateness " entails a division between a recent and a more remote past. Where the boundaries fell and how these pasts were ordered was negotiated anew every time. Simon MacLean has recently drawn our attention to how Regino of Prüm used the Annales regni Francorum in his reconstruction of the history of Charlemagne. For the entry under the year 813, Regino remarks, "I discovered the things which have been laid out above in a certain booklet composed in the language of plebeians and rustics. ${ }^{13} \mathrm{~A}$ piece of writing propagated by the court and used as a "narrative of triumph « is thus devalued here, quite astonishingly. ${ }^{14}$ But in light of his comments on the scholarship of Antiquity, which, in Regino's view, was cultivated by Archbishop Hatto in his own time, we can come to the conclusion that a gap had been created between the present and the more recent past. This is not the »floating gap " which Jan Assmann writes about as that moving boundary which separates cultural from communicative memory and which has been transmitted through first-hand experience. ${ }^{15}$ Rather, this gap is created by Regino himself. Events from the past are actively made bad. ${ }^{16}$ For Notker, a monk of St Gall and the author of an idiosyncratic biography of Charlemagne intended for Charles the Fat only twenty years earlier than Regino, the age of Charlemagne had been represented as a Golden age in comparison to ignavia moderna ${ }^{17}$ Either way, the expression of feeling late was a powerful tool for creating awareness and sensitivity for the present.

9 Synod of Tribur, ed. Hartmann et al., 343.

10 Abbo of Saint-Germain, Sermo adversus raptores, ed. Önnerfors, 285-287. See also West, Fratres.

Regino, Libri duo de synodalibus causis, ed. Hartmann, 21.

Regino, Libri duo de synodalibus causis, ed. Hartmann, 21.

Regino of Prüm, Chronicle, s.a. 813, trans. MacLean, 129.

Airlie, Narratives of triumph.

Assmann, Kulturelles Gedächtnis.

MacLean, Insinuation.

17 Notker Balbulus, Gesta Karoli Magni imperatoris 2.16 ed. Haefele, 81; Goetz, Historiographisches Zeitbewußtsein, 165 . 
Another technique for arranging the past is to deny that it contained events that were meaningful or worthy of memory. Concerning the era of Louis the Pious, Regino reports, "I have not found written texts, nor heard from the seniores anything that was worth committing to memory ${ }^{18}{ }^{18}$ Simon MacLean has rightly pointed out that such an expression is extremely strange in light of the surviving manuscript material from that very period, ${ }^{19}$ but Regino clearly would not and was not required to report anything concrete about this time. By 900, stories, reports and texts about Louis the Pious and his successors were clearly no longer so important as to be expected or demanded by the audience of a historiographical text. Applied to this very political aspect of social life, this meant that the early Carolingians - even Charlemagne and Louis the Pious - were no longer necessarily as central to identity as before, or perhaps should no longer have this function, according to Regino himself. Their histories were at least not so familiar and cared for, not to say protected, that a reader or recipient of the text would immediately look up in consternation when he read Regino's dismissive comments. Similar processes can be observed in historiographical texts from different regions. The disappearance of the Armenian lay and clerical elites following the Byzantine annexation of the principality of Taron in the tenth century, for instance, allowed the unknown author of the History of Tarōn to subvert centuries-old practices in his text and to reshuffle the historical meaning of churches, monasteries and other cult sites in order to justify the "radical transformation« in the ecclesiological landscape happening in their own time.

Freed of limitations, taking liberties with dates could also be another technique. With Regino in particular, we can observe looseness with years: Lothar married Theutberga in 855, not in 856 as mentioned in the Chronicle; the Treaty of Verdun was concluded in 843, not in 842 ; the first attack by the Northmen on the banks of the river Loire happened in 843 , not in 853; Nominoe, king of the Bretons, died in 851 and not in 862 , and so on. ${ }^{20}$ Some of these erroneous datings are due to the devaluation of this era, while others are entirely due to the author's calculations with the aim of lending an exaggerated importance to selected events and identifying a turning point. Again, Regino of Prüm provides an example of how to arrange events in order to create meaning. The key event in Regino's Chronicle took place in 888. In the passage referring to this year, he vividly describes the crisis of political authority that erupted in the Carolingian Empire after Charles the Fat's deposition and death. After Charles's death, chaos, lack of hierarchy and lack of hegemony prevailed. ${ }^{21}$ Even Arnolf, a hero in the Annals of Fulda, for instance, "was only simply one more ruler in what was now a landscape crowded with rulers «, as Stuart Airlie put it. ${ }^{22}$ To highlight the immediate effects of Charles's death, a clear break with a glorious past had to be illustrated. Regino assigned this role to the Hungarians, who were a new, alien people on the borders of the Frankish realms with the potential to become a real threat to the larger social whole (in contrast to the Northmen, who raided Prüm in 882 and 892, but were never described in the Chronicle

Regino, Chronicle, s.a. 813, trans. MacLean, 129.

19 MacLean, Carolingian past, 19.

20 Regino, Chronicle, s.a. 856, 842, 853, 862, trans. MacLean 135, 132, 133, 138; Goetz, Historiographisches Zeitbewußtsein, 169. But see West, Knowledge, 151-153, who refers to a lack of sources in Trier due to a Viking raid in 882 .

21 Regino, Chronicle, s.a. 888, trans. MacLean, 198-202.

22 Airlie, "Sad stories«, 121-122. 
in similar fashion). In the entry for the year 889 , he therefore offers a long excursus on the gens Hungrorum "... who were more savage than any beast«, and who threatened the entire empire. ${ }^{23}$ In the first years of the tenth century, when Regino wrote the Chronicle, it was obvious to everyone how dangerous the Hungarians really were, because everybody was acquainted with their raids in northern Italy in 899/900. But no other contemporary source reports Hungarian raids in 889 or in the next two years. It is only in 892 that the Annals of Fulda tell us about Hungarians fighting for Arnulf of Carinthia, king of East Francia, against the Moravians. ${ }^{24}$ To put the excursus on the Hungarians in the account of 889 was therefore a dramaturgical decision by the historian. It was meant to frame an important moment of late Carolingian history - the death of Charles the Fat - with an appropriate threat. But there is more: Regino of Prüm wrote the Chronicle for Louis the Child in 908 for a purpose, as Simon MacLean and Eric Goldberg argue in their contribution of this issue. To safeguard the future of Carolingian rule in East Francia, Regino hoped to influence the king's inner circle to select an appropriate royal bride. Because of this, it was appropriate to suppress bad news about the royal family. Connecting the Hungarian threats with Charles the Fat's death helped to conceal the responsibility of Arnulf, Louis the Child's father, for the steppe-riders' introduction into Carolingian polities. Rumours were circulating that Arnulf once opened the gates of Europe to the marauding Hungarians. Moreover, the young king had failed to protect his realm against the Hungarians, especially in the battle of Bratislava in 907, when a large number of Bavarian aristocrats had lost their lives. In locating the appearance of the Hungarians in the context of the death of Charles the Fat, responsibility for the rising power of the steppe riders and the inadequate defensive measures of 907 was neatly shifted to events and circumstances which occurred before the ruling king was even born. 888 was clearly a gap in history for Regino of Prüm and his contemporaries, ${ }^{25}$ but 889 was intentionally created for the reasons mentioned above.

Authors from different regions used selected chronological frames in order to give their narratives a specific orientation. The unknown author of the Chronicle of Albelda for instance used biblical computations in order to create an historical account in eras which framed the rules and deeds of the Roman kings and emperors. To Eduardo Manzano this chronological order was "a hint of a divine plan that was unfolding in the course of time« and which should culminate in efforts by the Asturian kings to expel the Muslims from Iberia. Employing a similar technique in late tenth-century Armenia, Uxtanēs of Sebasteia merged an already existing History of the Armenians with a list of Roman emperors, split into seventeen sections. In doing so, the author provided the Armenian past not only with a chronological framework, as Timothy Greenwood argues, but also with symbolic meaning, because between Aeneas and Romulus there had been 17 kings.

For many authors in the Middle Ages, but explicitly for Regino of Prüm, creating the past meant actively "forgetting " the deeds of earlier generations, talking their cultural heritage down, identifying turning points in the history of the realm or of a people, and re-arranging events in order to create a new narrative. It is characteristic of this period of transformation 
that there are thresholds between different pasts. This again does not correspond to the floating gap (of 80 to 100 years) which separates communicative from cultural memory, as defined by Jan Assmann. ${ }^{26}$ The immediate past is naturally always more (socially) real, more threatening, more political. It must be described more precisely, with care, caution and calculation. Regino demonstrates this as well, by being forced by his own involvement in Lotharingian politics into mere insinuations and even a gap in the text. ${ }^{27}$ In times of transition, authors are confronted with a number of events that cannot be placed into a simple narrative strand, like the rebellion of Louis the Pious' sons in 830 , which had consequences for the continuation of one of the most influential historiographical texts of this time. The Frankish Royal Annals stopped because it was no longer possible to reach a consensus about the text "as the valid narrative of the Carolingian past and present", as Helmut Reimitz put it. ${ }^{28}$ In the following decades the political conditions became more confused, obliging the authors to make manifold decisions and weigh up their positions in order to build a reliable narrative of what had happened. Simon MacLean and Eric Goldberg demonstrate in their contribution how prudently the legitimacy of Louis the Child is strengthened, while his opponent's (Charles the Simple's) line of descent is carefully but decisively devalued throughout Regino's Chronicle. Prudence was advised, because the West Frankish king, Charles, showed an interest in Lotharingia, where Regino lived and wrote his text. ${ }^{29}$ In a similarly complicated situation, Uxtanēs of Sebasteia wrote a sophisticated history on the relations between Romans and Armenians in the last years of the tenth century, in a time when Armenians in and around Sebasteia were divided in ecclesiological matters into factions which supported or opposed the Imperial, i.e. Byzantine, Church.

The liberty of choice has its advantages, but also several disadvantages. Above all, there is no centre of authority, no hegemon, who makes it easier for the author to present his text as the expression of this dominant authority. This all leads to the authors perceiving themselves as actors and presenting themselves actively in their texts. This applied to Regino of Prüm as well as to Liudprand of Cremona, Flodoard of Reims and Widukind of Corvey. They have all integrated autobiographical notes into their works. ${ }^{30}$ In his Chronicle, Regino reflects more than once on his replacement as abbot of Prüm ${ }^{31}$ The second book of the Chronicle becomes much more detailed in 892, when his deposition took place. The concentration on the more recent past was already dealt with in Regino's entry for 813:

26 Assmann, Kulturelles Gedächtnis.

27 Regino, Chronicle, s.a. 892, trans. MacLean, 212-214.

28 Reimitz, History 425.

29 About this and other political factions see MacLean, Insinuation, 12-15.

30 Flodoard of Reims, Historia Remensis ecclesiae, 4.28, ed. Stratmann, 419. Widukind of Corvey, Rerum gestarum Saxonicarum 1.1, ed. Hirsch and Lohmann, 4; Liudprand of Cremona, Antapodosis, 3.1, ed. Chiesa, 68.

31 Regino, Chronicle, s.a. 892 and 899, trans. MacLean, 212-214 and 224; MacLean, Insinuation, 12. 
"Concerning the times of the emperor Louis [the Pious, 814-40] I have included very little because I have not found written texts, nor heard from the elders anything that was worth committing to memory. However, I have more to say about the deeds of the emperor Lothar [I, 840-55] and his brothers, the kings of the Franks. And where it comes up to our own times, I have made my narrative broader: sfor things we have seen<, as Jerome says, rare told in one way, and those we have heard in another: those things we know better, we also explain better.« ${ }^{32}$

In the first place, it was the rupture in his biography, which explains the broadening of the narration. Secondly, in a society built around a strong dynastic centre, the cultivation of memory reaches very far back: old stories have a longer effect; there are obligations which go back decades, rhetorical understandings as to how many events are dealt with, norms about what can be passed over and what can be mentioned. Regino deals with all this rather summarily, as the political landscape had changed completely after Louis the Pious.

When these obligations towards the past no longer exist, or are no longer important (at least on the surface), then this gap can be expressed clearly, as Regino does in his devaluation of the time of Louis the Pious. Another example is offered by the Annals of Quedlinburg, compiled in the first years of the eleventh century, which have a gap between 873 and 910 . This is in no way due to some kind of lack of knowledge, but rather the concern to make allowance for the beginning of a new power in the East Frankish Kingdom. The entry for 873 ends with the report of a great famine in Germania. In the previous year, the church of St. Mary in Hildesheim (which was highly important for the Ottonians) had been consecrated by Bishop Altfrid. ${ }^{33}$ The entry for 911 reports the death of Louis the Child and the succession of Conrad - the first non-Carolingian and elected king. But in 913 the really important event is noted: the death of Otto the Illustrious, Duke of Saxony, the father of Henry I - he is labelled stemma imperatoria in the text. Above all, attention is drawn to the birth of Otto the Great in the same year..$^{34}$ Between the years of 873 and 910, every single year is listed, but not filled out with a narrative. This visual desert, from whose barren horizon only the death of the last Carolingian ruler stands out before the new material begins, is presaged by natural disasters, as recorded in the annals for $862,867,868,872$ and $873 .{ }^{35}$ In the Germania plagued by famine and laid waste by locusts, the most fruitful tree of the propago Otthonum took root, which would be of the greatest importance for all Europa, as the annalist notes.

In this example, not only the length of time is important, but also the scales of observation and the ranges of rulership. We see an expansion from "Germania« to "Europa«. Liudprand of Cremona also announces in his Antapodosis that he will, coming from this Ottonian perspective, report the "deeds of the Emperors and Kings of all Europe«. ${ }^{36}$ But he begins his text with Fraxinetum (today's La Garde-Freinet, France). This is a very notable change of scale: from "all Europe« to a small, unimportant locality, which, according to Liudprand, had once been captured by no more than twenty Muslims. ${ }^{37}$ The inclusion of this place and 
event did not come out of nowhere: this focus on Fraxinetum is clearly a hidden message for Recemund, the Christian bishop to whom Liudprand dedicated his text and who served as 'Abd al-Rahman III's ambassador to the court of Otto I. ${ }^{38}$ Naturally, Fraxinetum was known to Liudprand's contemporaries. In the second quarter of the tenth century the Muslims of Fraxinetum regularly raided transalpine travellers..$^{39}$ Ultimately the Muslims had kidnapped Maiolus, the abbot of Cluny, and the Saracens were an important power in their own right in the Mediterranean area. ${ }^{40}$ Moreover, it was not that far from Cremona, where Liudprand himself was based, and, on top of this, King Berengar, whom Liudprand rejected, came from Provence. In this regard, the treatment of Fraxinetum in the Antapodosis is no exception to the rule. Generally, it should be kept in mind that the focus of historiographical texts is often concentrated on smaller places and events, but to begin a historiographical text in such a place is a notable exception. In contrast to older texts, this narrative does not start with a noteworthy event that can immediately be situated within a larger social whole, for example with the death of Emperor Charles the Fat, which could have furnished a framework into which the attack on Fraxinetum could be situated. Quite the opposite - the author draws attention to a small, insignificant, nearly banal event in the past in an unimportant place, which nonetheless, over the course of time, developed to a considerable threat, an insignificant injury that became a festering wound.

Through this choice of beginning, Liudprand indirectly points to the fragmentation of western Europe in the late-Carolingian past - a Europe without a centre, divided into kingdoms, in which the ranges of power were not sufficient to fend off intruders; a fragmented society, in which the range of enemies could easily expand because of a lack of unity among neighbours. The change of scale in the first pages of Liudprand's work makes a clear break with the past, both in terms of content and form. As we can see here, a period of transition is a time when scales are shifted.

The shift in power relations was reflected in all areas of life. In the 920 s there were six or seven kings in the former (Carolingian) empire and only one of them was a "Carolingian". The drifting apart of the Carolingian Empire, which had already begun in the middle of the ninth century, had already had an effect on historiographical texts at that point. Already in the ninth century, the focus of the Annales Bertiniani is on Western Francia, while the Annales Fuldenses focus on the eastern realm. ${ }^{41}$ But even there, several centres provided focal points, such as Mainz, Fulda and Regensburg. ${ }^{42}$ The narratives orient themselves increasingly according to alternative scales. Flodoard in his Historia Remensis ecclesiae concentrated on »regional histories« rather than only on political history, which had consequences for his annals as well. ${ }^{43}$ Above all, in the place of historiographical works we see the rise of Gesta episcoporum, which place bishops and the history of their bishoprics centre stage: the scale

38 Liudprand, Antapodosis, 3; Leyser, Ends and means.

39 Flodoard of Reims, Annales s.a. 921, 923, 929, 931 etc., ed. Lauer, 5, 19, 44-45, 47 etc.; Bruce, Cluny and the Muslims, 29.

40 Bruce, Cluny and the Muslims, 6-12.

41 Annales Bertiniani, ed. Waitz; trans Nelson.

42 Annales Fuldenses, s.a. 830-863 (= Continuatio Fuldensis), s.a. 864-887 (= Continuatio Mogontiacensis), s.a. 882897 (= Continuatio Ratisbonensis), ed. Kurze.

43 Flodoard of Reims, Historia Remensis ecclesiae, ed. Stratmann. 
has thus become smaller. ${ }^{44}$ In this, the scale follows the diminution in the range of rulership, for instance in the case of Arnulf's precarious rule in Italy and Lotharingia even narrated by the Annales Fuldenses..$^{45}$ The Annales Fuldenses also demonstrate the smaller political range of Arnulf of Carinthia, who was able to assert himself against Zwentibald in Italy but not in Lotharingia. The diminution in factual political rulership is also the theme of many narratives about counts and other potentes. Thus Count Boso of Burgundy, characterised as malevolent in the Vita of Johannes of Gorze, is criticised with regards to his behaviour, as his rulership effectively ends outside his area of office. The roads in his area are plagued by bandits. ${ }^{46}$

The choice of scale depended on the position of the author and of the audience he was writing for. In his contribution to this issue Timothy Greenwood observes a focus in Armenian historiography of the tenth century upon the districts and regions of the south and the east. Whilst the reason for this focalisation is difficult to determine, the scale of the historical works changed according to the political situation in Armenia: in times of active resistance against the Byzantine rule the focus was narrower. But when the benefits of the Byzantine Empire became apparent for the Armenian elite, Step'anos Taronec'i wrote The Universal History, demonstrating the great risks in ceasing their resistance. Obviously becoming a smaller part of a big empire encouraged the author to report about the bad deeds of Roman emperors in a large-scale history.

In late Carolingian societies, though, serious problems of dissolution prevailed. The reduction of areas of power at various levels also conditioned changes in territorial names and group names. The Carolingian imperium once shaped groups in different ways and held them together. Consequently, it was not only the confusing past which bothered the authors of the late ninth/beginning of the tenth century. The definitions or the common denominators of social groups themselves now had to be (re)negotiated. Old designations such as Gallia comata began to surface again. New names for enemies were dug up from older texts, such as the Getae for the Northmen, which the monk Ulmarus took from Jordanes. ${ }^{47} \mathrm{New}$ names drawn from Antiquity were applied to various political situations, such as the gens Tungrorum for the rebellious people of Liège, who, in the author's view, have the "wrong" bishop; or the gens Aquitanica, referring to the rebels of that province. ${ }^{48}$ From the early 870 , the Annales Fuldenses refer to the Bavarians alternatively as Baiuvarii and Norici (and the latter are distinguished from the Slavs). Norici is a modification of the name of an old Roman province, which in reality no longer fit. ${ }^{49}$ Obviously, in the late Carolingian world antique names helped authors to identify the changed political conditions; similarly the Chronicles of northern Spain made extensive use of Biblical denominations to identify the political and cultural Other.

\footnotetext{
44 Riches, The changing political horizons.

45 Annales Fuldenses, s.a. 893-899, ed. Kurze 122-133.

46 Hystoria de vita, c. 105, 1 and 107-108, ed. Jacobsen, 394-395 and 400-403.

47 Ulmarus, Libellus de virtutibus, cc. 1 and 2, ed. Holder-Egger, 399.

48 Abbo of Saint-Germain, Sermo adversus raptores, ed. Önnerfors, 94-99, trans. Cross and Brown, 285-7. Adrevald of Fleury, Miracula Sancti Benedicti, c. 23, ed. Holder-Egger, 495.

49 Annales Fuldenses, s.a. 877, 882, 884 and 887, ed. Kurze 90, 98, 101 and 106.
} 
Moreover, these repertoires also enabled authors to understand and explain complex social and political relations. Justin's Epitome, for instance, helped Regino of Prüm set the divergent forces of a society into precise language, not merely by reporting internal conflicts but also by reflecting on them. In this, the decisive factor is the level of reflection. ${ }^{50}$ But mostly the texts these terms were taken from had their own specific notions of social cohesion and belonging, and more importantly, they offered alternative political frames. Texts from the more distant, pre-Carolingian past especially helped in distancing oneself from the more recent Carolingian past. The use of Vergil's Georgics and Eclogues presented an idealised image of the era of Augustus, which could be contrasted with the later Carolingian Empire. The acts of martyrs and accounts of their translations emphasised the Christian roots of Europe. As Geoffrey Koziol put it, "The very frame of history has changed from empire to Church, where the Church is an apostolic foundation led by bishops and nourished by the blood of martyrs. ${ }^{51}$ From this perspective, we can also see how texts written by Gregory the Great in around 600 became a resource for episcopal authority in the era after the Carolingian Empire. Gregory's letter collection "was a mirror [for bishops on] how to survive, and indeed to prosper in a world otherwise spinning out of control. $^{52}$

The change to alternative frameworks was not limited to matters of content, but was also put into words through the use of other forms of text. In the second half of the ninth century, the number of hagiographical texts rose considerably, mainly because of numerous relic translations imposed by pressure from Norman and Hungarian raids. Martyrologies, like that of Usuardus, promised to provide spiritual stability for monastic communities in an ever changing world. In contrast, in the tenth century, annals nearly disappeared. Regino's decision to compose a chronicle was a conscious invocation of an older tradition. On the whole, historiographic texts became notably fewer, but in compensation, poetry was employed more. Abbo of Saint Germain cast the account of the defence of Paris against the Northmen in the last years of the ninth century in verse. ${ }^{53}$ In 906, Bishop Salomon of Constance expressed his concerns about the Empire under the reign of Louis the Child in a long epistolary poem..$^{54}$ And the Gesta Berengarii imperatoris was written in around 920 in more than 1000 hexameters. ${ }^{55}$ Every author had his own reasons for choosing this genre. Abbo of Saint-Germain in any event focused on specific events, which he then formed into a turning-point for Frankish history: the defence of Paris in the time of the disintegration of the Carolingian realm and the advent of a new ruler, Odo of Paris. The epic nature of these events was underpinned by the use of dactylic hexameter, and, what is more, the form of verse allowed a more or less synchronic representation of the divergent events which naturally occur in battle. Moreover, the Viking raids on Paris reported here stretched from the year 885 to 896 and were arranged year after year. In this way, a typically Carolingian format, namely that of annals, was chosen to represent a diachronic

50 Regino, Chronicle, s.a. 890, trans. MacLean, 290.

51 Koziol, Future of history, 29.

52 Leyser, Memory, 197.

53 Abbo of Saint Germain, De bello Parisiaco, ed. von Winterfeld

54 Salomon of Constance, Carmen, 1, ed. von Winterfeld.

55 Gesta Berengarii imperatoris, ed. von Winterfeld. 
chain of events. This, however, required squeezing events into a narrative strand, which in this time-period was often no longer successful: from the 860s/870s onwards, for example, the Annals of Fulda had to include information from other decades in their yearly entries, in order to make the events of every year understandable. The events of Paris were thus "double-formatted" and so formed a watershed between the (recent) past and the present.

In order to create a past, authors active around 900 used different strategies: they chose specific text formats in order to distance themselves from the past; they employed alternative sources and a new vocabulary; they changed the scale of their observation and took new liberties with their narratives, as they were not quite as firmly bound to inherited narratives as their predecessors. This also had an effect on their authorial posture within their texts.

Through their specific use of the past, these texts not only attempted to provide an image of a new reality, they went beyond this: their efforts to break the present off from the past, or to emphasise certain aspects of the past and to "forget « others, makes clear that they were making an essential contribution to the re-formation of their world.

Each of the authors and actors whose works and deeds are discussed in the following articles had the difficult task of handling the past. Not all of them used written records, but dealt either with oral tradition, like the lay advocates and notaries who discussed legal customs in tenth-century Raetia, or reused the material culture of a long-ago era, like the caliphs of al-Andalus, who reused Roman sarcophagi and statues as an active process of appropriation and reinterpretation of Antiquity. Some of the authors and actors were confronted with the social and discursive effects of fragmentation. In their respective articles Simon MacLean, Eric Goldberg, and Stefan Esders analyse two important aspects of transforming the Carolingian past: the question of legitimacy and continuation of the ruling dynasty, and the role of legal customs and written law in a period when the empire broke apart and governmental structures became regionalised. In both cases old traditions and practices were re-evaluated in order to make the present fit for a promising future. Stefan Esders also underlines that legal pluralism was already established at the very beginning of the Carolingian Empire, a postulation which is also valid for other areas of social, political and cultural life in the first half of the ninth century. The idea of fragmentation often leads to inappropriate conclusions, for instance that the central region of an empire remains culturally and politically decisive after its breakdown.

However, it was not only in the Carolingian heartland regions, such as Lotharingia and Raetia, that Carolingian texts and traditions remained important, but also in the border regions or in neighbouring kingdoms like Catalonia and England. Matthias Tischler demonstrates in his contribution how the very periphery of the Carolingian Empire, Catalonia, became a centre of Carolingian knowledge and manuscript transmission in the ninth to the eleventh centuries, despite older literature qualifying the long tenth century as a "dark age « of literacy.

A large number of Carolingian books had also already reached England by the end of the ninth century, such as Usuard's Martyrology, a volume containing stories on late antique martyrs' lives and deaths. In contrast to genuine early English martyrologies, the Carolingian texts focused on the historicity of the material, thus creating a Church history of the ancient past. In her contribution Sarah Hamilton investigates how the "historical-mindedness" of Carolingian churchmen like Usuard was passed to their tenth and eleventh century successors in early Medieval England and how this text shaped the society in which it was read.

While the Latin West reflected on Carolingian political styles and texts, most of the Spanish peninsula was part of the dar al-Islam, which, although it clearly differed from the Christian world, nevertheless based its knowledge on the same cultural legacy from Late Antiquity 
as the Christian kingdoms in the North. In their paper Eduardo Manzano Moreno and Jorge Elices Ocón compare the use of this classical heritage in both cultural milieus in times of crisis and transition.

Late antique cultural heritage and the Christian past were important sources for many authors in the successor states of the Roman Empire in the entire Mediterranean area and beyond. The Byzantine expansion to the east led to a serious crisis in tenth-century Armenia, provoking contemporary authors to rewrite Armenian history on the basis of late antique sources and Church history. Timothy Greenwood examines three different historiographical works, which deal with Roman-Armenian encounters in the past. The role of saints and their cult sites was particularly significant in defining the past. That was also the case in early Medieval Georgia, where disputes about the confessional identity of the kingdom Kartli - pro or contra Chalcedonian - determine the historiography until today, as Emma Loosley Leeming demonstrates in her contribution. The past was and is still today a source of identity.

The long tenth century certainly had its ups and downs in most of the regions discussed in this themed issue, but it cannot just be qualified as a »dark « or »iron« age, stressing the downside of fragmentation, conflict, violence and cultural decline, as is traditionally argued for the tenth-century Latin West. ${ }^{56}$ Expanding the focus will allow similar processes and events happening on a larger scale to be recognised. The contribution from Alice Hicklin on social and discursive traditions of hostage-giving from Ireland to China demonstrates how many writers in these different parts of the world experimented, often in a very similar manner, with "new modes and models of approaching their past, responding to their present«. Sometimes there is no need to go very far to become aware of alternative dynamics of transformation in this period. The Spanish peninsula alone provides decisive findings in this respect. Despite, or even due to, constant conflicts and tensions between the Christian North and the Islamic South, both cultures produced extraordinary texts. In tenth-century Umayyad Spain the Historiae adversos paganos of Paulus Orosius were translated into Arabic and adapted for Islamic history, while in Catalonia the so-called Luculentius Homiliary tackled, on the basis of classical texts, the religious, political and social problems of this frontier society including the relationship to the Muslims. The middle ground between the Carolingian and Mediterranean worlds was indeed an intellectually and culturally fertile area. Like this example, all the contributions in this themed issue show that master narratives like that of the "decline of an empire« often conceal a wide range of social practices and critical discourses on smaller scales. Times of transition in general and the long tenth century in particular can be regarded as periods of experimentation and of exceptional productivity, especially when it comes to the "uses of the past«.

\section{Acknowledgements}

This thematic issue goes back to a three-year HERA project on "After Empire. Using and Not Using the Past in the Crisis of the Carolingian World, c. 900-1050 « in the Universities Barcelona (UAB), Berlin (FU), Exeter, Saint-Andrews and the Austrian Academy of Sciences in Vienna between 2016 and 2019. 


\section{References}

Abbreviations

MGH = Monumenta Germaniae Historica

Abbo of Saint Germain, De bello Parisiaco, ed. Paul von Winterfeld, MGH Poetae latini aevi Carolini 4.1 (Berlin, 1899) 72-122.

Abbo of Saint-Germain, Sermo adversus raptores bonorum alienorum, ed. Ute Önnerfors, Abbo von Saint-Germain-des-Pres, 22 Predigten, Lateinische Sprache und Literatur des Mittelalters 16 (Frankfurt am Main, 1985) 94-99. English translation: James E. Cross and Alan Brown, Literary impetus for Wulfstan's Sermo Lupi, Leeds Studies in English, n.s. 20 (1989) 271-291.

Adrevald of Fleury, Miracula Sancti Benedicti, ed. Oswald Holder-Egger, MGH Scriptores 15.1 (Hanover, 1887), 474-497.

Airlie, Stuart, Narratives of triumph and rituals of submission. Charlemagne's mastering of Bavaria, Transactions of the Royal Historical Society 6/9 (1999) 93-119.

Airlie, Stuart, "Sad stories of the death of kings". Narrative patterns and structures of authority in Regino of Prüm's Chronicle, in: Elizabeth M. Tyler and Ross Balzaretti (eds.), Narrative and History in the Early Medieval West (Turnhout, 2006) 105-131.

Annales Bertiniani, ed. Georg Waitz, MGH, Scriptores rerum germanicarum in usum scholarum ex Monumentis Germaniae historicis recusi (Hanover, 1883). English translation: Janet L. Nelson, The Annals of St-Bertin (Manchester, 1991).

Annales Fuldenses, Continuatio Ratisbonensis, ed. Friedrich Kurze, MGH Scriptores rerum Germanicarum in usum scholarum separatim editi 7 (Hanover, 1891).

Annales Quedlinburgenses, ed. Martina Giese, MGH Scriptores rerum Germanicarum in usum scholarum seperatim editi 72 (Hanover, 2004).

Assmann, Jan, Das kulturelle Gedächtnis. Schrift, Erinnerung und politische Identität in frühen Hochkulturen (Munich, 2007).

Bruce, Scott G., Cluny and the Muslims of La Garde-Freinet. Hagiography and the Problem of Islam in medieval Europe (Ithaca, 2015).

Diesenberger, Maximilian, Straining after effect. Regino of Prüm, the death of Charles the Fat and the Hungarians, in: Walter Pohl and Francesco Borri (eds.), Historiography and Identity 5. The Emergence of New Peoples and Polities, 1000-1300, Cultural Encounters in Late Antiquity and the Middle Ages (Turnhout, forthcoming).

Epistola de Hungaris, ed. Konrad Josef Heilig, Der Brief des Remigius von Auxerre um 900 über die Ungarn, in: Historisches Jahrbuch des Ungarischen Graf-Klebelsberg-Instituts 3 (1933) 7-30.

Flodoard of Reims, Annales, ed. Philippe Lauer, Les Annales des Flodoard (Paris, 1905).

Flodoard of Reims, Historia Remensis ecclesiae, ed. Martina Stratmann, Monumenta Germaniae Historica, Scriptores 36 (Hanover, 1998).

Gantner, Clemens, Rosamond McKitterick and Sven Meeder (eds.), The Resources of the Past in Early Medieval Europe (Cambridge, 2015).

Geary, Patrick J., Phantoms of Remembrance. Memory and Oblivion at the End of the First Millennium (Princeton, 1994).

Gesta Berengarii imperatoris, ed. Paul von Winterfeld, MGH Poetae latini aevi Carolini 4.1 (Berlin, 1899) 355-401. 
Goetz, Hans-Werner, Historiographisches Zeitbewußtsein im frühen Mittelalter. Zum Umgang mit der Zeit in der karolingischen Geschichtsschreibung, in: Anton Scharer and Georg Scheibelreiter (eds.), Historiographie im frühen Mittelalter, Veröffentlichungen des Instituts für Österreichische Geschichtsforschung 32 (Vienna, 1994) 158-178.

Hen, Yitzhak and Matthew Innes (eds.), The Uses of the Past in the Early Middle Ages (Cambridge, 2000)

Huygens, Robert B. C., Un témoin de la crainte de l'an 1000. La lettre sur les Hongrois, Latomus 15 (1956) 225-239.

Hystoria de vita domni Iohannis Gorzie coenobii abbatis, ed. Peter Christian Jacobsen, MGH Scriptores rerum Germanicarum in usum scholarum seperatim editi 81 (Wiesbaden, 2016).

Innes, Matthew, Introduction. Using the past, interpreting the present, influencing the future, in: Yitzhak Hen and Matthew Innes (eds.), The Uses of the Past in the Early Middle Ages (Cambridge, 2000) 1-8.

Koziol, Geoffrey, The future of history, in: Stefan Esders, Sarah Greer and Alice Hicklin (eds.), After Empire. Using and not Using the Past in the Crisis of the Carolingian World, c. 90oc.1050 (forthcoming).

Leyser, Karl, Ends and means in Liudprand of Cremona, in: Timothy Reuter (ed.), Communications and Power in Medieval Europe. The Carolingian and Ottonian Empires, (London, 1994), 125-142.

Leyser, Karl, The memory of Gregory the Great and the making of Latin Europe, 600-1000, in: Kate Cooper and Conrad Leyser (eds.), Making Early Medieval Societies. Conflict and Belonging in the Latin West, 300-1200 (Cambridge 2016) 181-201.

Liudprand of Cremona, Antapodosis, ed. Paolo Chiesa, Corpus Christianorum, Continuatio Mediaevalis 156 (Turnhout, 1998) 1-150.

MacLean, Simon, The Carolingian past in post-Carolingian Europe, in: John G. H. Hudson and Sally Crumplin (eds.), The Making of Europe. Essays in Honour of Robert Bartlett (Leiden, 2016) 11-31.

MacLean, Simon, Insinuation, censorship and the struggle for late Carolingian Lotharingia in Regino of Prüm's Chronicle, The English Historical Review 124/506 (2009) 1-28.

Notker Balbulus, Gesta Karoli Magni imperatoris, ed. Hans F. Haefele, MGH Scriptores rerum Germanicarum, n.s. 12: Notker der Stammler, Taten Kaiser Karls des Großen (Berlin, 1959).

Pohl, Walter, Historiography and identity. Methodological perspectives, in: Walter Pohl and Veronika Wieser (eds.), Historiography and Identity 1: Ancient and Early Christian Narratives of Community (Turnhout, 2019) 7-50.

Pohl, Walter, and Ian Wood, Introduction: cultural memory and the resources of the past, in: Clemens Gantner, Rosamond McKitterick and Sven Meeder (eds.), The Resources of the Past in Early Medieval Europe (Cambridge, 2015) 1-12.

Regino of Prüm, Chronicon, ed. Friedrich Kurze, MGH Scriptores rerum Germanicarum in usum scholarum (Hanover, 1890). English translation: Simon MacLean, History and Politics in Late Carolingian and Ottonian Europe. The Chronicle of Regino of Prüm and Adalbert of Magdeburg (Manchester, 2009).

Regino of Prüm, Libri duo de synodalibus causis et disciplinis ecclesiasticis, praefatio, ed. and trans. Wilfried Hartmann, Das Sendhandbuch des Regino von Prüm, Freiherr-vom-SteinGedächtnisausgabe 42 (Darmstadt, 2004).

Reimitz, Helmut, History, Frankish Identity and the Framing of Western Ethnicity, 550-850 (Cambridge, 2015). 
Riches, Theo, The changing political horizons of Gesta episcoporum, in: Ludger Körntgen and Dominik Waßenhofen (eds.), Patterns of Episcopal Power. Bishops in 1oth and 11th Century Western Europe (Berlin, 2011), 51-62.

Salomon of Constance, Carmen, ed. Paul von Winterfeld, MGH Poetae Latini aevi Carolini 4.1 (Berlin, 1899) 296-306.

Synod of Doucy (5 August-6 September 871), ed. Wilfried Hartmann, MGH Concilia 4: Die Konzilien der karolingischen Teilreiche 860-874 (Hanover, 1998) 410-572.

Synod of Fismes (April 881), Praefatio, ed. Wilfried Hartmann, Isolde Schröder, and Gerhard Schmitz, MGH Concilia 5: Die Konzilien der karolingischen Teilreiche 875-911 (Hanover, 2012) 166-200.

Synod of Moret (ca. 850), Letter of Erchanrad of Paris, ed. Wilfried Hartmann, MGH, Concilia 3: Die Konzilien der karolingischen Teilreiche 843-859 (Hanover, 1984) 232-234.

Synod of Tribur (Mai 895), ed. Wilfried Hartmann, Isolde Schröder, and Gerhard Schmitz, MGH Concilia 5: Die Konzilien der karolingischen Teilreiche 875-911 (Hanover, 2012) 319-415. Synod of Trosly (26 June 909), ed. Wilfried Hartmann, Isolde Schröder, and Gerhard Schmitz, MGH Concilia 5: Die Konzilien der karolingischen Teilreiche 875-911 (Hanover, 2012), 497-562.

Ulmarus, Libellus de virtutibus sancti Vedasti episcopi, ed. Oswald Holder-Egger, MGH Scriptores 15.1 (Hanover, 1887).

West, Charles, Fratres, omni die videtis cum vadit istud regnum in perdicionem. Abbo of SaintGermain and the crisis of 888, Reti Medievali Rivista 17/2 (2016) 301-317.

West, Charles, Knowledge of the past and the judgement of history in tenth-century Trier. Regino of Prüm and the lost manuscript of Bishop Adventius of Metz, Early Medieval Europe 24/2 (2016) 137-159.

Widukind of Corvey, Rerum gestarum Saxonicarum libritres, ed. Paul Hirsch and H.E. Lohmann, MGH Scriptores rerum Germanicarum in usum scholarum separatim editi 60 (Hanover, 1935).

Zimmermann, Harald, Das dunkle Jahrhundert. Ein historisches Porträt (Graz, 1971). 